\title{
Serotyping, virulence gene expression and phenotypic characterization of $E$. coli 0157:H7 in colibacillosis affecting buffalo calves in Basra governorate
}

\author{
H.A. Naji ${ }^{1}$, W.M.M. Saleh ${ }^{1 *}$, M. Hanoon ${ }^{2}$, I. $\operatorname{Imad}^{3}$ and Y. Salim $^{3}$ \\ ${ }^{1}$ Department of Internal and Preventive Veterinary Medicine, ${ }^{2}$ Department of Public Health, College of Veterinary Medicine, \\ University of Basrah, ${ }^{3}$ Veterinarian, Basra, Iraq, ${ }^{*}$ email: wessamgm@gmail.com
}

(Received November 5, 2018; Accepted December 23, 2018)

\begin{abstract}
The objective of the current study was to detect the clinical signs of colibacillosis in buffalo calves, isolate $E$. coli O157:H7, detect its virulence gene eaeA using PCR and estimate its prevalence. The current study sampled 120 buffalo calves aged 1day to 5 months from the Al- Basra veterinary Hospital and Private veterinary clinic within the Basra province between October 2017 and July 2018. A total of 100 calves were naturally diarrheic and the other 20 calves served as controls. The clinical sings in the diarrheic subjects included a significant increase in body temperature, heart rates, respiration rates and capillary refill time as compared to control group. Other clinical signs included whitish to yellowish watery diarrhea with tincture of blood, anorexia, weakness, depression, weak suck reflex, dry oral mucous membranes, cold extremities, weak peripheral pulse, dehydration and death. Using phenotypic characterization tools like MacConky agar, EMB agar, biochemical tests and Viteck, 83 out 100 diarrhea samples confirmed E. coli. Using CT- SMACT agar, 31 out of 83 E. coli isolates were $E$. coli $\mathrm{O} 157: \mathrm{H} 7$ positive. The PCR result indicated that 47 out of the 83 isolated $E$. coli samples were positive for $e a e A$ virulence gene. In conclusion, this study is a debut in the report of E. coli and E. coli O157:H7 isolation and genes identification in buffalo calves in Iraq. Therefore, proper prevention and control measures are requisite to curtail the mortality and morbidity rate caused by Colibacillosis.
\end{abstract}

Keywords: Colibacillosis, E. coli O157:H7, Buffalo calves, Basra, Iraq Available online at http://www.vetmedmosul.com

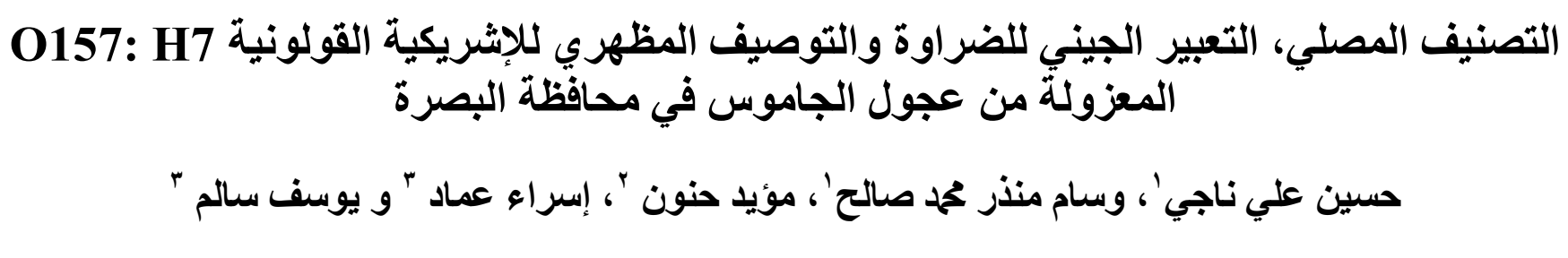

'فرع الطب الباطني والوقائي، ‘فرع الصحة العامة، كلية الطب البيطري، جامعة البصرة، ׳طبيب بيطري، البصرة، العراق

الخلاصة

كان الهدف من الدراسة الحالية تحديد العلامات السريرية التي تسببها الإصابة بالاشريشكية القولونية في عجول الجاموس و عزل عترة

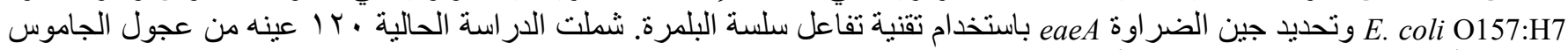

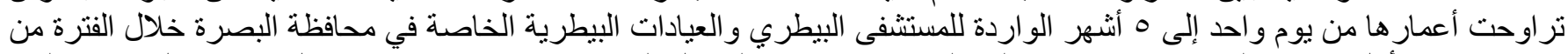

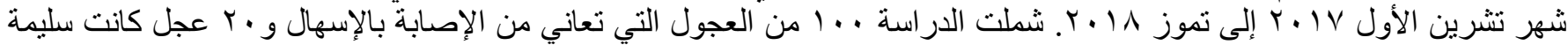

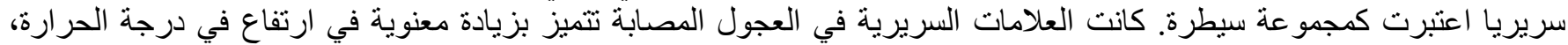

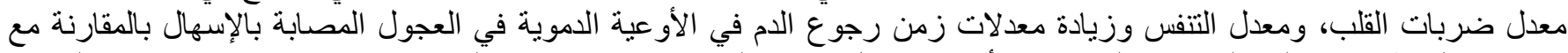

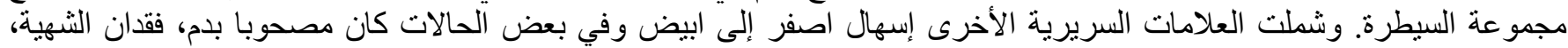




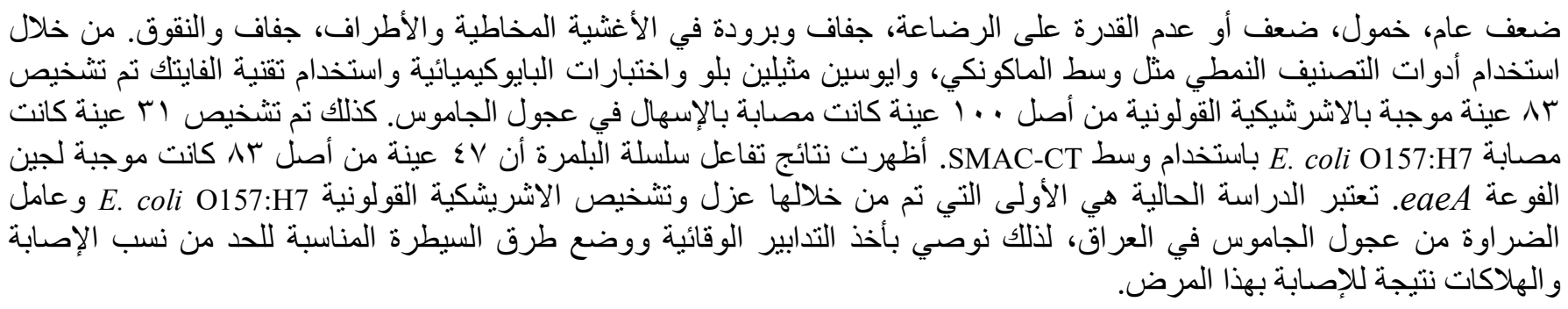

\section{Introduction}

Colibacillosis is a challenging and debilitating disease affecting the cattle industry (1). It is caused by a multiple range of aetiological agents, out of which Escherichia coli was recognized as the most important bacterial cause (2). Colibacillosis occurs in all age groups of animals with morbidity up to $50 \%$ (1). Escherichia coli belong to a large group of bacteria of the family Enterobacteriaceae. These commensal bacteria are harmless and mostly found in the large intestine of birds and mammals. Although few strains of $E$. coli can cause disease conditions like pyelonephritis, diarrhea and pneumonia $(3,4)$. Five different classes of $E$. coli that causes diarrhea are enteroinvasive, enterotoxigenic, enteropathogenic, enteroaggregative and enterohemorrhagig (5). The species $E$. coli is a gramnegative straight cylindrical rod like, non-spore-forming bacilli, measuring 1.1-1.5*2.0-6.0 $\mu \mathrm{m}$, they are aerobic and facultative anaerobic in nature, rendered motile by peritrichous flagella $(6,7)$.

Escherichia coli typing is based on the capsular $(\mathrm{K})$ polysaccharide, somatic $(\mathrm{O})$, flagellar $(\mathrm{H})$ antigens is used in epidemiology (8). Escherichia coli (E. coli $\mathrm{O} 157: \mathrm{H7})$ is a toxin producing bacteria that causes intestinal diseases in humans and animals resulting into bloody diarrhea. Severe cases can as well lead to life threatening kidney problems especially in children and neonates. Domestic and wild animals serve as carriers of this bacteria as it has been isolated and identified in cattle, sheep, pigs, deer, dogs and poultry $(9,10)$. But cattle have been pinned as the main carrier (11). Infected animals, especially the young ones shed the bacteria in their faeces, the livestock get infected by $E$. coli $0157: \mathrm{H} 7$ via ingestion of the bacteria in contaminated feeds, fomites and feces of infected animals (12).

This important group of diarrheagenic $E$. coli is characterized by the ability to induce attaching and effacing $\mathrm{A} / \mathrm{E}$ lesions on intestinal epithelium, and absence of Shiga toxin production $(13,14)$. A chromosomal pathogenicity island designated locus of enterocyte effacement (LEE) contains the genes responsible for the $\mathrm{A} / \mathrm{E}$ phenotype, among them eae and tir, which encode for an outer membrane protein called intimin and its translocated receptor Tir, respectively (15). The diarrheagenic E. coli causes high morbidity and mortality rate in claves resulting into a huge economic loses (16).

There is paucity of information on this diarrheagenic $E$. coli in buffalo in Basra- Iraq, as no documented data avails. Therefore, the present study aimed at unveiling this dearth of knowledge on Collibacilloisis caused by E. coli $\mathrm{O} 157: \mathrm{H} 7$ in buffalo in Basra using phenotypic and molecular techniques.

\section{Materials and methods}

\section{Animal and study design}

The present study was conducted on 120 buffalo calves aged 1day to 5 months old, a total of 100 calves were naturally suffering from diarrhea and 20 clinically normal calves served as negative control. The study period was between October 2017 to July 2018 in the College of Veterinary Medicine, Al-Basra Veterinary Hospital and another private veterinary clinic with Basra province.

\section{Clinical examination}

Diarrheic calves were examined and scores of vital signs were properly recorded and documented.

\section{Samples and bacterial isolate}

Rectal swab samples were collected from the calves using sterile swab sticks. Samples were then cultured on MacConkey agar and Eosin Methylene blue agar (Lab M, UK) and incubated aerobically at $37{ }^{\circ} \mathrm{C}$ for 48 hours. Thereafter, growing colonies were phenotypically characterized for and $E$. coli samples were identified. $E$. coli positive cultured samples were further grown on Cefixime Tellurite - Sorbitol MacConkey agar (CT-SMAC) to detect the E. coli O157:H7. Further confirmation was done using biochemical tests and Veitick. The virulence gene eaeA was finally detected using PCR.

\section{DNA extraction and Polymerase chain reaction (PCR)}

DNA of the $E$. coli isolate was extracted using bacteria DNA extraction kit (Promega / USA) following the manufacturer's instructions. The PCR technique was used to detect the polymorphisms of the virulence gene (eaeA) using forward and reverse primers (GACCCGGCACAAGCATAAGC and 
CCACCTGCAGCAACAAGAGG, respectively) (17). The primers were designed by Alpha DNA in Canada. Amplification reaction was performed using a DNA thermo-cycler, $1.5 \%$ agarose gel electrophoresis was stained with ethidium bromide under UV light (Table 1).

Table 1: The reaction mix $(25 \mu \mathrm{l})$ of multiplex PCR

\begin{tabular}{lc}
\hline Chemicals & Volume \\
\hline PCR green master mix & $12 \mu 1$ \\
Primer forward & $1 \mu 1$ \\
Primer reverse & $1 \mu 1$ \\
DNA & $3 \mu 1$ \\
Deionized distilled water & $8 \mu 1$ \\
\hline
\end{tabular}

\section{Statistical analysis}

All data were analyzed statistically using IBM SPSS software "version 11.5, copyright (C) 2019". Data was considered statistically significant at $(\mathrm{P}<0.05)$.

\section{Results}

The results from 100 fecal swabs taken from diarrheic buffalo calves had 83 samples confirmed as $E$ coli based on phenotypic characterization. Out of the $83 \mathrm{E}$. Coli isolates, 72 isolates were confirmed based on vietick test, about 31 isolates were detected as E. coli $\mathrm{O} 157: \mathrm{H7}$ based on SMACCT Agar (Fig. 1). The suspected colonies of E. coli O157:H7 appeared small, circular colorless with smoky center 1-2 mm in diameter on Sorbitol MacConky agar plus cefixime - potassium tellurite (SMAC-CT). Table 2 shows results of biochemical test on the bacterial isolate.

Table 2: Biochemical tests results

\begin{tabular}{cccc}
\hline Genus & Simmons Citrate & Urease & Indol test \\
\hline E coli & Negative & Negative & Positive \\
\hline
\end{tabular}

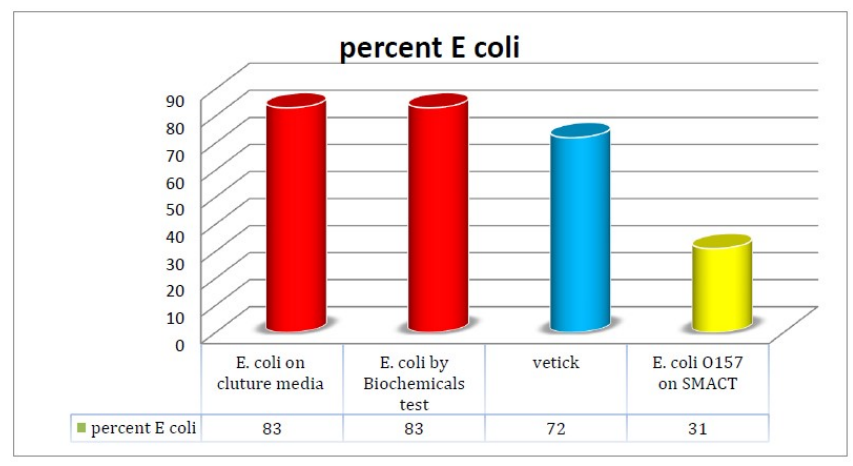

Figure 1: The percentage of E. coli depended on method isolation.

\section{Clinical signs}

The results of present study showed that the calves during the first 4 weeks of life are more susceptible for infection (Fig. 2).

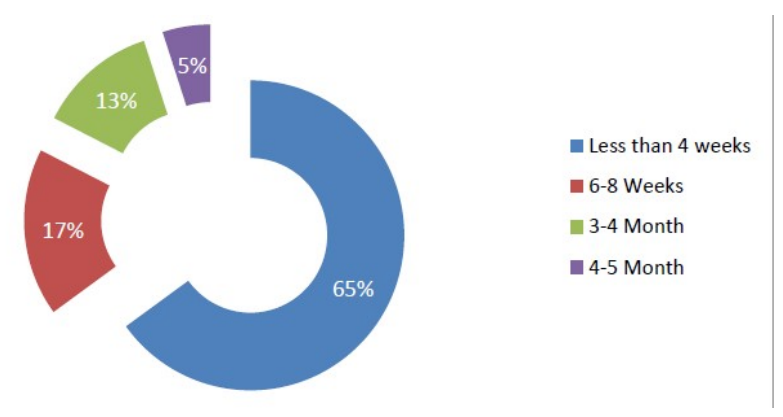

Figure 2: Relation between age and infection.

The clinical sings in diarrheic calves which confirmed infection with $E$ coli were a significant increase in body temperature, heart rates, respiration rates and Capillary refill time as compared to control group (Table 3).

Table 3: physiological parameters in infected animals and control groups

\begin{tabular}{lcc}
\hline Parameter & $\begin{array}{c}\text { Control } \\
\text { group } \pm \mathrm{SE}\end{array}$ & $\begin{array}{c}\text { Infected } \\
\text { group } \pm \mathrm{SE}\end{array}$ \\
\hline Body temperature ${ }^{\circ} \mathrm{C}$ & $39.25 \pm 0.51$ & $41.7 \pm 0.46^{* *}$ \\
Heart rate $/$ mint & $93.73 \pm 7.44$ & $109.3 \pm 4.41^{* *}$ \\
Respiratory rate/ mint & $37 \pm 3.05$ & $52 \pm 5.22^{* *}$ \\
Capillary refill time & $1.8 \pm 0.12$ & $5.2 \pm 1.3^{* *}$ \\
\hline$* * \mathrm{P}<0.01$ values are mean \pm stander error of mean.
\end{tabular}

Other clinical signs were white to yellow watery diarrhea with tincture of blood, anorexia, weakness, depression, weak sucking reflex, dry mucous membranes, cold extremities, weak peripheral pulse, dehydration and death (Table 4).

Table 4: Clinical sings in infected animals

\begin{tabular}{ll}
\hline Clinical signs & Numbers (\%) \\
\hline Yellow diarrhea & $56(67.4 \%)$ \\
Bloody diarrhea & $17(20.48 \%)$ \\
White diarrhea & $10(12.04 \%)$ \\
Anorexia & $71(85.54 \%)$ \\
Weakness & $62(74.69 \%)$ \\
Depression & $59(71.08 \%)$ \\
Dehydration & $53(63.85 \%)$ \\
Oral mucous membranes are dry and cool & $48(57.83 \%)$ \\
Weak peripheral pulse & $44(53.0 \%)$ \\
Cold extremities & $31(37.34 \%)$ \\
Death & $23(27.71 \%)$ \\
\hline
\end{tabular}




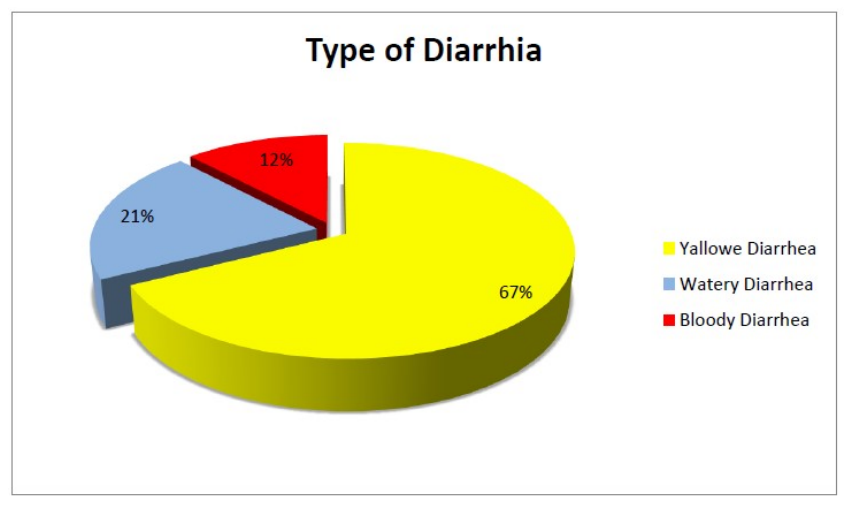

Figure 3: Types of diarrhea in infected animals.

The results of PCR showed that out of 83 isolates that were positive to $E$ coli via cultural and biochemical methods, only 47 isolates were positive for virulence gene eaeA using PCR (Fig. 4).

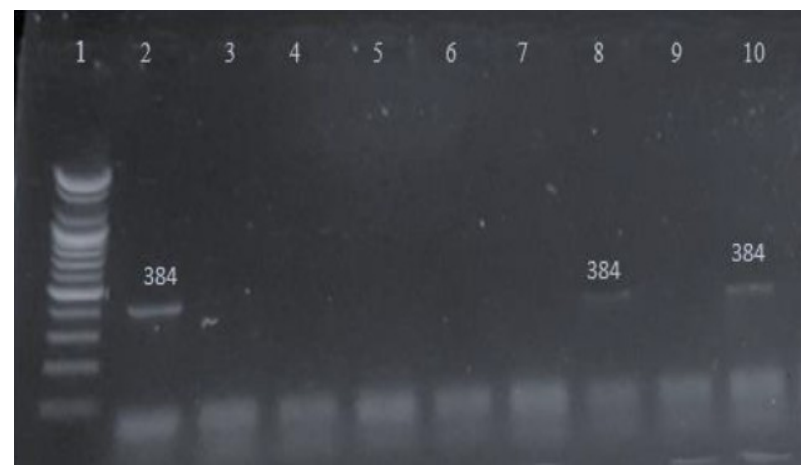

Figure 4: PCR detection of $E$. coli virulence gene eaeA at amplification of $384 \mathrm{bp}$ as visualized using agarose gel electrophoresis. Lane 1,8 and 10 were positive for eaeA virulence other lanes were negative.

\section{Discussion}

The results of the present study indicated that gram stain and other biochemical tests used in the study revealed that $E$. coli was responsible for disease condition observed in the sampled calves. This present finding is in resonance with those documented by 15 . The $E$. coli $\mathrm{O} 157: \mathrm{H} 7$ positive result obtained from the CT-SMAC test is in agreement with the reports of Garcia et al; Alani $(18,19)$. The authors found out that a typical E. coli O157:H7 appeared as colorless colonies and did not ferment sorbitol on SMAC agar while most non-O157 strains fermented sorbitol appeared as pink color colonies on SMAC agar.

The current study also indicated that calves within the first 4 weeks of life are more susceptible to the infection as this might be due to the systemic inflammatory response syndrome to an active infectious process. This finding correlates with the reports of Constable et al; Alani; Biolatti et al $(9,19,20)$. These authors have associated the quantum of susceptibility of this infection to young calves majorly due to low levels of serum IgG in calves and inadequate colostrum intake. They also submitted that the illness is per acute with a course varying from 24 to 96 hours having a survival rate less than $12 \%$.

Findings in the present study also revealed that the observed diarrhea in this infection varies from watery yellow to bloody diarrhea in infected calves. We can opine that the diarrhea occurs due to Enterotoxigenic effects of $E$. coli (ETEC) strains that colonize and proliferate in the upper small intestine and produce enterotoxins, thereby, causing an increase in net secretion of fluid and electrolytes into the gut lumen and hence the resultant diarrhea. This result is in total agreement with the findings of Alani; Fakih et al $(19,21)$. Other reports have also supported the fact the bacteria can colonize and hence proliferate in the intestinal epithelial (16). Thirty in their report have referred the adhesion of $E$. coli to intestinal epithelial cells has been mediated by bacterial pili. The bacterial fimbriae attach to specific receptor sites on villous epithelial cells, following which the bacteria multiply and forms microcolonies that cover the surface of the villi.

The increase in body temperature observed in the current study might indicate the liberation of endogenous and exogenous pyrogens such as a heat-stable enterotoxin and capsular polysaccharide. This is quite in harmony with the findings of Constable et al (9). Constable had reported that the bacteria toxins exerts effect on the thermoregulatory center of the hypothalamus thereby altering the thermostatic level. The other clinical signs such as heart rate, respiratory rate, capillary refilling time, weakens, dehydration is similar to those observed and reported by Constable et al; Cundon et al; Caceres et al $(9,22,23)$. These authors reported that the production of the enterotoxin results in net secretion of fluid and electrolytes from the systemic circulation into the lumen of the intestine, resulting in varying degrees of diarrhea, dehydration, electrolyte imbalances, acidemia, circulatory failure, shock, and death.

The results of present study indicated that the prevalence of eaeA gene was $56.62 \%$ as only 47 out of 83 isolates of $E$. coli were positive. This is typical of the findings of Alani, 2016. Alani had earlier reported that the percentage of eaeA gene was $53.12 \%$. However, the result of the current study is lower than that reported by Synge et al; Schouten et al; Alam and Zurek (24-26). These authors have reported that all tested isolates of Escherichia coli 0157:H7 in cattle were positive for eaeA in their various studies. These discrepancies in the prevalence report by different authors might be associated to due to different models and numbers of experimental animals, different 
diagnostic technique and geographical locations where such studies were carried out.

The public health outcry is that the eaeA positive isolates can causes intimate adherence, attaching and effacing lesions in intestinal epithelial cells of both human and animal. Therefore, this suggests a potential threat to the public health sector. The eaeA gene had been found in $E$. coli strains which do not belong to the EPEC serotypes and which are negative for shiga-toxins, and these strains have also been referred to attaching and effacing E. coli (27).

In conclusion therefore, this present study is a debut and the first to document the prevalence of $E$. coli and E. coli $\mathrm{O} 157: \mathrm{H} 7$ as it relates to colibacillosis in buffalo calves in Basra - Iraq.

\section{References}

1. Antaki-Zukoski EM, Li X, Pesavento PA, Nguyen THB, Hoar BR. Comparative pathogenicity of wildlife and bovine Escherichia coli O157:H7 strains in experimentally inoculated neonatal jersey calves. Vet Sci. 2018; 5(4):88-98. https://doi.org/10.3390/vetsci5040088

2. Vandekerchove D, De Herdt P, Lacvens H, Pasmans F. Colibacillosis in battery- caged layer hens: clinical and bacteriological characterstics and risk factor analysis. Avian Pathol. 2004; 33(2):117-125. http://hdl.handle.net/1854/LU-540081

3. Pianciola L, Rivas M. Genotypic features of clinical and bovine Escherichia coli $\mathrm{O} 157$ strains isolated in countries with different associated-disease incidences. Microorganisms. 2018; 6(36):1-16. doi: 10.3390/microorganisms6020036

4. Zhao HX, Zhao JL, Shen JZ, Fan HL, Guan H, An XP and Li PF. Prevalence and molecular characterization of fluoroquinolone resistance in Escherichia coli isolates from dairy cattle with endometritis in China. Microb Drug Resist. 2014; 20(2):162-169. doi: 10.1089/mdr.2013.0073

5. Markey B, Leonard F, Archambault M, Cullinane A, Maguire D. Clinical veterinary microbiology. $2^{\text {nd }}$ ed. Boston: Elsevier; 2014. 2:246-249.

6. Scheutz F, Strockbine NA. Bergey's manual of systematic bacteriology. New York: Springer; 2005. 5:607-624.

7. Mishra S, Agrawal D. A concise manual of pathogenic microbiology. London: John Wiley and Sons; 2013.71-75. doi/abs/10.1002/9781118301234

8. Stenutz R, Weintraub A, Widmalm G. The structures of Escherichia coli O-polysaccharide antigens. FEMS Microbiol. 2006; 30(3):382403. doi.org/10.1111/j.1574-6976.2006.00016.x

9. Constable PD, Hinchcliff KW, Done SH, Grünberg W. A textbook of the diseases of cattle, horses, sheep, pigs, and goats. $11^{\text {th }}$ ed. New York: Saunders Ltd; 2017. 1879-1883.

10. Kim M, Kuehn LA, Bono JL, Berry ED, Kalchayanand N, Freetly $\mathrm{HC}$, Benson AK, Wells JE. The impact of the bovine faecal microbiome on Escherichia coli $\mathrm{O} 157: \mathrm{H} 7$ prevalence and enumeration in naturally infected cattle. J Appl Microbiol. 2017; 123(4):1027-1042. doi: 10.1111/jam.13545.

11. Um MM, Brugère $H$, Kérourédan $M$, Oswald $E$, Bibbal $D$. Antimicrobial resistance profiles of enterohemorrhagic and enteropathogenic Escherichia coli of serotypes O157:H7, O26:H11, O103:H2, O111:H8, O145:H28 compared to Escherichia coli isolated from the same adult cattle. Microb Drug Resist. 2018; 24(6):852-859. doi: $10.1089 / \mathrm{mdr}$.

12. Central for Diseases Control. National Center for Emerging and Zoonotic Infectious Diseases (NCEZID) 2015. https://www.cdc.gov/ncezid/what-we-do/publications-2015.html
13. Kaper JB. Defining enteropathogenic Escherichia coli (EPEC). Proceedings of the International Symposium on Enteropathogenic Escherichia coli (EPEC). Rev Microbiol. São Paulo. 1996; 27:130-133.

14. Carter MQ, Brandl MT, Kudva IT, Katani R, Moreau MR, Kapur V. Conditional function of autoaggregative protein cah and common cah mutations in shiga toxin-producing Escherichia coli. Appl Environ Microbiol. 2017; 84(1):1-17. doi: 10.1128/AEM.01739-17.

15. Frankel G, Phillips AD. Attaching effacing Escherichia coli and paradigms of Tir-triggered actin polymerization: Getting off the pedestal. Cell Microbiol. 2008; 10(3):549-556. DOI: 10.1111/j.14625822.2007.01103.x

16. Thiry D, Saulmont M, Takaki S, De Rauw K, Duprez JN, Iguchi A, Piérard D, Mainil JG. Enteropathogenic Escherichia coli O80:H2 in young calves with diarrhea, Belgium. Emerg Infect Dis. 2017; 23(12):2093-2095. doi: 10.3201/eid2312.170450.

17. Randall LP, Cooles SW, Osborn MK, Piddock LJ, Woodward MJ. Antibiotic resistance genes, integrons and multiple antibiotic resistance in thirty-five serotypes of Salmonella enterica isolated from humans and animals in the UK. J Antimicrob Chemother. 2004; 53:208-216. DOI: $10.1093 / \mathrm{jac} / \mathrm{dkh} 070$

18. Garcia A, Fox J, Besser T. Zoonotic enterohemorrhagic Escherichia coli: A one health perspective. ILAR Journal. 2010; 51(3):221-232. PMID: 21131723

19. Alani MA. Prevalence and molecular characterization of Escherichia coli $\mathrm{O} 157: \mathrm{H} 7$ in calves [PhD dissertation]. Baghdad: College of Veterinary Medicine, Baghdad University; 2015. 78-79.

20. Biolatti C, Bellino C, Borrelli A, Capucchio M, Gianella P, Maurella C, Miniscalco B, Nebbia P, Zoppi S, Cagnasso A. Sepsis and bacterial suppurative meningitis-meningoencephalitis in critically ill neonatal piedmontese calves: Clinical approach and laboratory findings. Schweiz Arch Tierheilkd. 2010; 154:239-246. DOI: 10.1024/00367281/a000339

21. Fakih I, Thiry D, Duprez JN, Saulmont M, Iguchi A, Piérard D. Identification of Shiga toxin-producing (STEC) and enteropathogenic (EPEC) Escherichia coli in diarrhoeic calves and comparative genomics of O5 bovine and human STEC. Vet Microbiol. 2017; 202:16-22. DOI: 10.1016/j.vetmic.2016.02.017

22. Cundon C, Marey E, Roldán F, Canosa Montero CS, Navarro A, Padola N L. Detection and Characterization of Preliminary Escherichia coli 0174 Producing Toxins. Buenos Aires: SNS Publicación periodística científico-tecnológica. 2015; 2314-2901. http://digital.cic.gba.gob.ar/handle/11746/5746

23. Cáceres ME, Etcheverría AI, Fernández D, Rodríguez EM, Padola NL. variation in the distribution of putative virulence and colonization factors in shiga toxin-producing Escherichia coli isolated from different categories of cattle. Front Cell Infect Microbiol. 2017; 28(7):147-153. doi: 10.3389/fcimb.2017.00147

24. Synge BA, Chase ME, Hopkins GF, McKendrick IJ, Thomson F, Gray D, Rusbridge SM, Munro FI, Foster G, Gunn GJ. Factors influencing the shedding of verocytotoxin-producing Escherichia coli O157 by beef suckler cows. Epidemiol Infect. 2003; 130(2):301-312. DOI: $10.1017 / \mathrm{s} 0950268802008208$

25. Schouten JM, Bouwknegt M, van de Giessen AW, Frankena K, De Jong MC, Graat EA. Prevalence estimation and risk factors for Escherichia coli $\mathrm{O} 157$ on dutch dairy farms. Prev Vet Med. 2004; 64(1):49-61. DOI: 10.1016/j.prevetmed.2004.03.004

26. Alam MJ, Zurek L. Seasonal prevalence of Escherichia coli O157:H7 in beef cattle feces. J Food Prot. 2006; 69(12):3018-3020. PMID: 17186673

27. Hedayatianfard K, Akhlaghi M, Sharifiyazdi H. Detection of tetracycline resistance genes in bacteria isolated from fish farms using polymerase chain reaction. Vet Res Forum. 2014; 5(4):269-275. PMCID: PMC4299992 